Jason Kehrberg*

\title{
Authoritarianism, Prejudice, and Support for Welfare Chauvinism in the United States
}

https://doi.org/10.1515/spp-2019-0008

Received November 25, 2019; accepted June 16, 2020

\begin{abstract}
This article examines the role of authoritarianism in shaping individual policy support for creating a waiting period before legal immigrants can access welfare programs. I use logistic regression models to analyse the opinions of nonLatino whites from the 1992 American National Election Study (ANES). I find that authoritarianism is related to a waiting period before immigrants can access welfare benefits, despite a significant number of non-authoritarians also preferring a waiting period. This effect is robust with the inclusion of several traditional predictors of welfare attitudes.
\end{abstract}

Keywords: authoritarianism, immigration, prejudice, social conformity, welfare chauvinism

Since 1965, the size of the immigration population has significantly increased from a record low to a nearly record high in the United States. ${ }^{1}$ With the increasing foreign-born population, immigration became a controversial issue shaping political opinions with mass attitudes taking a central and important role in policy adoption. In what is described as the "new politics of immigration", political elites and the mass media framed immigration as a normative threat to government services resulting in a strong preference for more restrictive programs (Calavita 1996). For example, support for denying immigrants access to welfare or welfare chauvinism (Banting 2000; Faist 1994), gained national prominence with the adoption of California's Proposition 187 and the Personal Responsibility and Work Opportunity Reconciliation Act of 1996. In this article, I examine public support for

1 In 1970, immigrants were 4.7\% of the U.S. population. By 1990, the estimated immigrant population grew to $7.9 \%$ and by 2017 , the estimated immigration population was $13.7 \%$ of the U.S. population.

*Corresponding author: Jason Kehrberg, Political Science and Criminal Justice, Muskingum College, 43762-1118, New Concord, Ohio, USA, E-mail: jekehrberg@gmail.com 
welfare chauvinism to better understand the underlying influences for creating citizenship barriers to government services. Understanding this policy preference is important due to the role that public opinion holds in influencing the inclusivity of state welfare programs (Hero and Preuhs 2007; Kehrberg 2017) and immigrant policies (Abrajano and Hajnal 2015; Butz and Kehrberg 2016, 2019; Monogan 2013).

An extensive literature demonstrates that a wide range of considerations influence individual immigration policy preferences, including support for welfare chauvinism. Many studies emphasize the political economy of immigration. These studies focus on native concerns that immigrants represent labour market competition, a fiscal burden, and competition for scarce resources resulting in individual preferences for restricting immigration and immigrant access to social programs (e.g. Dustman and Preston 2007; Facchini and Mayda 2009; Gerber et al. 2017; Mayda 2006; Scheve and Slaughter 2001). Hanson, Scheve, and Slaughter (2007, p. 3), for example, argued that "immigration is likely to be evaluated by natives for not just its labour-market impacts but its fiscal impacts as well." On the other hand, a second body of research examines the socio-psychological influences on immigration attitudes (Hainmueller and Hopkins 2014). At the heart of these socio-psychological studies is the public perception that immigrants are culturally different and fail to assimilate American values, such as the fear of immigrants failing to adopt "proper” American social norms (e.g. Brader, Valentino, and Suhay 2008; Citrin et al. 1997; McDaniel, Nooruddin, and Shortle 2011). Perceived cultural differences between immigrants and natives create concerns about social conformity that drives anti-immigrant attitudes (Hetherington and Weiler 2009; Manevska and Achterberg 2013). At a first glance, economic considerations appear to have a more direct link to welfare chauvinism since social programs provide economic benefits from what is perceived to be limited resources, but can concerns about social conformity increase support for restrictive welfare policies?

Perceptions of non-conformity build tension between authoritarian values, such as social cohesion, and personal autonomy (Feldman 2003; Feldman and Stenner 1997; Stenner 2005), resulting in authoritarian preferences for restrictive and aggressive public policies towards minorities (Hetherington and Weiler 2009). Building on authoritarianism and immigration attitudes research, I theorize that the authoritarian worldview shapes welfare preferences as these policy preferences become "immigrationalized" for many non-Latino whites. Using the American National Election Study (ANES), my results reveal important findings about the nature of support for welfare chauvinism. First, the socio-psychological perspective influences individual support for the creation of welfare programs with restrictions. The significance of authoritarianism provides evidence for 
non-economic predictors for restrictive welfare policies. Authoritarianism can potentially create a constituency that responds to anti-immigrant nativist appeals regardless of the economic threat or burden of immigrants. Second, authoritarians hold more negative stereotypes of Latinos, the racialization of immigration. Nonauthoritarians and authoritarians hold similar policy preferences among those prejudicial beliefs. The effect of authoritarianism is greatest among the nonprejudicial. Third, a large percentage of non-authoritarians supported creating a waiting period before immigrants could access welfare programs. Most likely, this result is based on the degree of issue salience of immigration. Potentially, during periods when immigration is considered an important issue that is linked to social welfare programs, non-authoritarians prefer restricting immigrant access to welfare, similar to authoritarians.

\section{Authoritarianism, Immigration, and Welfare Chauvinism}

Welfare policies are ethnically and racially neutral on the policy surface, but welfare programs become a mechanism for "defining structures of social and political inclusion and exclusion” (Lieberman 2003, p. 30) that is reflected in public opinion. The inclusion and exclusion of groups requires the construction of imagined communities creating group boundaries that can be defined in terms of acquiring and holding specific social norms (Anderson 1983). An imagined community creates a sense of bonds and connections to group members, individuals sharing the same social norms, and a willingness to support the wellbeing of ingroup members (Miller 1995). For in-group members, inclusive welfare policies provide support, but for out-group members, welfare programs can be viewed as providing resources to create parallel societies allowing them to resist social integration resulting in the continuation of the normative threat presented by outgroups. In this way, support for welfare is predicted by group identities with preferences for limiting access to out-group members by adopting restrictive policies (Kinder and Kam 2009; Stenner 2005; Theiss-Morse 2009).

The terms authoritarian and authoritarianism can be problematic due to the different uses. For example, many individuals picture leaders of certain political regimes when they think about the concepts of authoritarians and authoritarianism, such as Saddam Hussein, Bashar al-Assad, and Vladimir Putin (Hetherington and Weiler 2009). Another use of the terms is to study the differences in human behaviour and psychology (i.e. Adorno et al. 1950; Altemeyer 1981, 2003; Feldman 2003; Hetherington and Weiler 2009; Stenner 2005). For example, 
Adorno et al. (1950) researched authoritarianism as a personality trait. Their research was motivated to explain the mass support for the antidemocratic policies of Nazi Germany, ethnocentrism, and prejudice. Many of the earlier studies focus on a single dimension of authoritarians by viewing authoritarians as individuals who submit to authority (Altemeyer 1981). Authoritarianism has at least two additional dimensions beyond submission, social conformity and aggression (Altemeyer 1996). More recent studies have focused more on the dimensions of social conformity and aggression (Feldman 2003; Hetherington and Suhay 2011; Hetherington and Weiler 2009; Stenner 2005), and define authoritarianism as a general orientation "concerned with the appropriate balance between group authority and uniformity, on the one hand, and individual autonomy and diversity, on the other hand" (Stenner 2005, p. 14). Under this conceptualization, social conformity, defined as "a desire for an orderly and structured world" (Hurwitz and Peffley 1992, p. 400), is a key motivation for authoritarians' attitudes and policy preferences. A need for social order among authoritarians leads to a black-andwhite view of the world that distinguishes sharply between favoured in-groups and threatening out-groups (Altemeyer 1981, 1996; Feldman and Stenner 1997; Feldman 2003; Hetherington and Weiler 2009; Katz 1960; Stenner 2005; Walker 2009). Authoritarians are individuals with these three dimensions: a greater desire for social conformity, hold prejudicial attitudes towards "targeted" groups resulting in support for aggressive and punitive policies towards those groups, and support for stronger authority to enforce social conformity to create order (Altemeyer 2003; Hetherington and Weiler 2009).

Media framing shapes attitudes and policy preferences by shaping the considerations people use to form attitudes and the weight they place on those considerations (e.g. Chong and Druckman 2007; Nelson, Clawson, and Oxley 1997). These media influenced considerations are the situtuationalism in how immigration is viewed by the masses, which policies people connect to immigration, and the type of threat that natives perceive from immigrants (Chavez 2008; Lahav and Courtmanche 2012; Lahav 2013). The news media can create a false perception that immigrants are "unwilling or incapable of integrating, of becoming part of the national community" (Chavez 2008, p. 2) resulting in "the failure of MexicanAmericans over several generations to increase their identification with American values" (Huntington 2004, p. 242) being a commonly held belief. As a result, immigrants that fail to adopt social norms can be viewed as a threat to the present social order and as being outside of the "American" imagined community (Paxton and Mughan 2006; Schildkraut 2011). When a frame triggers a pre-existing and often used predisposing factor, such as authoritarianism, individuals are more likely to use that predisposing factor to interpret and react to the issue. For example, there is considerable evidence that the public views immigration as a 
racialized $^{2}$ issue and, as such, whites often conflate their views of Latinos and immigrants, and draw on their racial stereotypes to form immigration attitudes (e.g. Brader, Valentino and Suhay 2008; Burns and Gimpel 2000; Chavez 2008; Lu and Nicholson-Crotty 2010).

In this line of thought, authoritarianism acts as a worldview and a fundamental consideration that links strong emotional responses, such as fear and anxiety, about out-groups to government policies resulting in enduring political blocs. Authoritarians are much more likely than non-authoritarians to express prejudice towards a range of outgroups that are perceived to challenge the existing social and political order, such as immigrants. Perceptions of social differences between in-groups and out-groups provide the fertile breeding ground for authoritarians' negative views of out-groups and a preference for largely punitive policies that restrict the social, economic and political rights of outgroups to minimize perceived threats. For immigrants and Latinos, group boundaries help to "rationalize and justify governmental practices and policies that stigmatize and punish certain categories of immigrants and their children” (Chavez 2008, p. 42). These preferred policies include decreasing immigration levels and restricting government benefits and civil liberties of groups perceived to be racially or culturally different from "true" Americans (Adorno et al. 1950; Feldman 2003; Hetherington and Weiler 2009; Hetherington and Suhay 2011; Kinder and Kam 2009; Stenner 2005). As a result, authoritarians would have a preference for welfare policy "to become more aggressive in enforcing social order, defining behavioural expectations, and demanding self-discipline from the poor" (Soss, Fording and Schram 2011, p. 63). Based on this research, I hypothesize that immigrant groups that are branded as alien out-groups will be targeted by authoritarians for a series of harsh and punitive measures, such as creating waiting periods before immigrants can access welfare programs.

Authoritarianism and racial stereotypes are not mutually exclusive but entangled influences of political attitudes. As such, authoritarianism can be expressed through negative stereotypes forming prejudice towards out-groups. Stereotypes are conditional "pictures in the head" of labels representing perceived group characteristics that are used for relevant judgements (Hurwitz and Peffley 1997; Lippmann 1922). Racial stereotypes influence political attitudes when the policy relates to perceptions about a particular minority groups (Nelson and Kinder 1996). For example, Burns and Gimpel argue that "The association of immigrants with welfare use and the connection between welfare use and negative racial

2 I use the term racial as a synonym for ethnicity. Despite Latinos being an ethnic group and not a race, much of the scholarly literature and survey questions treat Latinos the same as racial minorities, such as Blacks, Asians, and Native Americans. 
stereotypes underscore how immigration can easily be translated into a racial issue with redistributive undertones" (2000, p. 207). This body of literature mirrors the studies on welfare preferences finding that racial stereotypes and concerns for social conformity undermine support for generous welfare programs (Gilens 1999; Hopkins 2009; Hurwitz and Peffley 1992; Johnson 2001; Peffley, Hurwitz, and Sniderman 1997). Previous research finds that authoritarians hold more negative stereotypes of several minority groups than non-authoritarians, such as Jews and African Americans (e.g. Sniderman and Piazza 1993; Hetherington and Wieler 2009; Stenner 2005). On the other hand, authoritarianism has been shown to be a weak predictor of a racial stereotype measure of ethnocentrism (Kinder and Kam 2009). Theoretically, authoritarians are probably concerned about the conformity of immigrants beyond standard measures of racial stereotypes, such as being hard working. The basis for authoritarian support of restrictive immigration policies can be due to the nature of immigrants being social and cultural outsiders, not just prejudicial stereotypes of them. In this possible scenario, authoritarians' preferences should remain the same regardless of their prejudice of Latinos.

\section{Data, Measurement, and Analysis}

The data for the analysis are from the ANES in 1992. The 1992 ANES includes several important features. First, I am unaware of another American survey that includes a measure of authoritarianism and welfare chauvinism. Second, the ANES uses the child-rearing questions to measure authoritarianism (Hetherington and Suhay 2011; Hetherington and Weiler 2009; Stenner 2005). The child-rearing measure has several advantages, such as being politically neutral, over other measures of authoritarianism. Unfortunately, the 1992 ANES has several disadvantages. First, ANES dataset lacks an adequate number of blacks and Latinos. Due to this restriction, I limit the samples to non-Latino whites. Second, the data is old but for several reasons, I do believe that the worldview divide found in this study would be significantly stronger in recent years. First, the worldview divide between authoritarianism and non-authoritarianism is believed to be constant or "timeless" (Hetherington and Weiler 2015). For example, research on authoritarianism and terrorism by Hetherington and Suhay (2011) find that authoritarians' attitudes and policy preferences towards terrorist suspects do not vary with the level of perceived threat. Second, additional research finds that authoritarianism is a constant predictor of many policy preferences across time (Cizmar et al. 2014). Third, over the last few decades the polarization in American politics has increased indicating that the divide on welfare chauvinism today is most likely to be greater than it was in 1992. Authoritarians have increasingly sorted into the Republican Party 
(Hetherington and Weiler 2009; Cizmar et al. 2014). This sorting has resulted in a growing divide between the Democratic and Republican parties over immigration, and as such, the divide I find in this paper would probably be larger in 2020 as nonauthoritarian Democrats adopt more positive immigration attitudes. These findings support the theory that authoritarianism is a stable worldview that should have a strongly consistent influence on public opinion.

\subsection{Dependent Variables}

The dependent variable is welfare chauvinism. To measure welfare chauvinism, I use a question that asks "Do you think that immigrants who come to the U.S. should be eligible as soon as they come here for government services such as Medicaid, Food Stamps, Welfare (coded as 0), or should they have to be here a year or more (coded as 1)?"3 An ideal question would allow more differentiation in responses and allow individuals to select a longer waiting period, such as 5 years, or even a permanent ban on benefits for immigrants. Nevertheless, although the variation in responses to the question is undoubtedly truncated, individuals with more restrictive preferences for immigrants' access to welfare should map onto the two responses, since a waiting period is closer to restrictive preferences than no waiting period. The positive aspects of this question are the simplicity of the wording and the question is adequate for this research project.

\subsection{Independent Variables ${ }^{4}$}

The two independent variables of interest are authoritarianism and prejudice towards Latinos. I measure authoritarianism with an additive index of four questions on childhood values (e.g. Hetherington and Suhay 2011; Hetherington and Weiler 2009; Stenner 2005). Each childhood values question asks respondents to choose between two desirable values for children, such as being independent or respectful of elders (the authoritarian value option). The wording of the battery stem is, "Although there are a number of qualities that people feel that children should have, every person thinks that some are more important than others. I am going to

3 All missing values are excluded from the analysis for the dependent variable. Descriptive statistics for the dependent variable: median $=1$, mean $=0.81$, standard deviation $=0.40$.

4 For the independent variables, the missing data is excluded from the analysis. All independent variables are coded on 0 to 1 scales, expect for the racial prejudice measure which ranges from -1 to 1. I report the results with the independent variables on their original scales in the appendix. The results are not significantly different due to these coding decisions. 
read you pairs of desirable qualities. Please tell me which one you think is more important for a child to have." This measure is designed to minimize social desirability bias and tap respondents' value priorities for order, conformity, and obedience to authority (Hetherington and Weiler 2009; Stenner 2005). The four sets of childhood value options are "being independent or respectful of elders", "selfreliance or obedience”, "curiosity or good manners", and "being considerate or being well behaved." The authoritarian values in this battery are "respect for elders”, “obedience”, "good manners”, and "being well behaved.” Each question is coded as 0 for non-authoritarian values, 0.5 for the percentage of respondents who volunteer that both values are equally important, and 1 for authoritarian values (Chronbach's alpha $=0.674) .{ }^{5}$ To recode the additive scale to range from a low of 0 to a high of 1 (indicating high authoritarianism), I added responses to the four questions together and divided by four (mean $=0.56$, standard deviation $=0.31$ ).

This measure has several advantages over traditional measures of authoritarianism, such as the F-Scale (Adorno et al. 1950) and the Right-Wing Authoritarianism (RWA) measure (Altemeyer 1981). As Feldman (2003) points out, previous measures of authoritarianism, such as Altemeyer's Right-Wing Authoritarianism index, included questions that asked about prejudice, intolerance, and conservatism, which made predicting prejudice and other concepts with authoritarianism tautological. By contrast, the child values measure is clearly distinct from the attitudes it is designed to predict (see Feldman 2003; Hetherington and Suhay 2011; Hetherington and Weiler 2009; Stenner 2005). ${ }^{6}$

Due to the racialization of immigration policy and the immigrationalization of welfare (Garand, Xu, and Davis 2017), prejudice towards Latinos are likely to influence welfare chauvinism. Respondents are told "Now I have some questions about different groups in our society. I'm going to show you a seven-point scale on which the characteristics of people in a group can be rated. In the first statement a score of 1 means that you think almost all of the people in that group are "rich." A score of 7 means that you think almost everyone in the group are "poor." A score of 4 means you think that the group is not towards one end or another, and of course you may choose any number in between that comes closest to where you think people in the group stand. Afterwards, the respondents are given a series of questions about different groups asking about work-ethic, intelligence, and violence.

5 The percentage of individuals who volunteered that both values are equally important ranges from 9.48 to $20.86 \%$.

6 For a more detailed examination of the construct validity of the child-rearing measure and how it relates to other measures of authoritarianism see Hetherington and Weiler (2009, pp. 51-58). 
To construct a measure of prejudice towards Latino, I code individual assessments for the work ethic, intelligence, and violence of "whites" and "Hispanics"7 on a 7-point scale ranging from negative (0) to positive attitudes (1). Previous scholars have suggested that respondents use different rating systems (e.g. Wilcox, Sigelman, and Cook 1989). For example, one respondent may view all groups as being hardworking and a second respondent may view all groups as being lazy. To make sure that the prejudice measure taps beliefs about Latinos and not a misanthropic view of everyone, scholars recommend subtracting ratings of the respondent's own racial group from ratings of the target group. For each individual stereotype measure, work-ethic, intelligence, and violence, I subtract Whites' ratings of "whites" from their ratings of "Hispanics". Each resulting stereotype ranges from -1 to 1 , with positive values indicating a belief that Latinos hold more positive traits than whites, and negative values indicate the view that whites are more hardworking, more intelligent, or less violent than Latinos. I combine these three stereotypes by taking the mean value creating a prejudicial measure of Latinos in relative terms to non-Latino whites' perceptions of their own racial group $($ mean $=-0.06$, standard deviation $=0.013){ }^{8}$

\subsection{Control Variables}

Control variables include measures of political identifications, ideology and partisanship, both of which are related to authoritarianism (e.g. Hetherington and Weiler 2009) and welfare attitudes (e.g. Carsey and Layman 2006; Sniderman and Carmines 1997; Sniderman and Piazza 1993). Authoritarianism is different than conservatism (Feldman 2003; Hetherington and Weiler 2009; Stenner 2005). Authoritarians are more likely than conservatives to "support radical changes in the existing social fabric if they can be persuaded that those changes are necessary to maintain order and quell threats to the social fabric" (Hetherington and Weiler 2009, p. 39). Political ideology is assessed on a seven-point scale asking respondents to self-place themselves on the ideological spectrum. Respondents are asked "We hear a lot of talk these days about liberals and conservatives. Here is a 7-point scale on which the political views that people might hold are arranged from extremely liberal to extremely conservative. Where would you place yourself on this scale, or have not you thought much about this?" The seven-point scale for

7 For the sake of consistency, I use the term "Latino" throughout the text of this manuscript. The American National Election Study uses the term Hispanic in the actual survey questions. The terms are interchangeable and I do not believe that the use of either term biases the results.

8 Kinder and Mendelberg (1995), Peffley and Hurwitz (2010), and Piston (2010) use a similar coding scheme to estimate racial stereotypes about Blacks relative to Whites. 
political ideology ranges from extremely liberal (0) to extremely conservatives (1) (mean $=0.54$, standard deviation $=0.23$ ). In addition to ideology, I include a measure for party identification. Authoritarians are increasingly sorting themselves into the Republican Party (Hetherington and Weiler 2009). I use a 7-point Party ID scale developed by the ANES based on multiple questions starting with an individual's general partisanship to how strongly or weakly they consider their partisanship. The partisanship scale ranges from "strong Democrat" (coded as 0) to "strong Republican" (coded as 1 ) (mean =0.49, standard deviation $=0.34$ ). In addition, individuals were given the option of picking "No preference" or "Other party." I decided to code these respondents as missing data.

Based on previous research, I include controls for individual level economics and several demographic characteristics. Economics and immigration attitudes are related (e.g. Lahav 2004; Quillian 1995; Scheepers, Gijsberts, and Coenders 2002; Sniderman, Hagendoorn, and Prior 2004), as well as, personal economics and welfare policy preferences (Gilens 1999). To measure economic self-interest, I follow Gilens and others by using a simple measure of yearly household income in constant dollars (mean $=0.51$, standard deviation $=0.25)$. The 1992 ANES question asks respondents to indicate the "letter of the income group that includes the income of all members of your family living here in 1991 before taxes.” Based on previous research, I include several demographic characteristics as control variables: education, female, and age. I include these demographic characteristics since each might shape individual policy preferences. I expect older individuals to prefer more restrictive immigration policies. Age is coded into four categories ranging from 18 to 29 (1) to 65 and older (4) (mean $=0.50$, standard deviation $=0.34$ ). More educated individuals should support more liberal immigrant policies. Education can influence a range of factors, from income to democratic attitudes. Research on immigration attitudes found that individuals with higher levels of formal education hold more positive attitudes towards immigrants (Hainmueller and Hiscox 2007; Voss, Kehrberg, and Butz 2013). To measure education, I use a question asking respondents "What is the highest degree that you have earned?" I coded the responses into a 4-point scale. The first category includes individuals who did not complete a high school degree (coded as 0). Respondents who have completed a high school degree are coded as 0.333. Individuals who are attending college or completed a 2-year degree are combined into a single category (coded as 0.667). For the final category, I combine individuals who have completed a bachelor's degree or an advanced degree into a single category (coded as 1 ) (mean $=0.53$, standard deviation $=0.35$ ). Finally, research has found that women (coded as 1) prefer more social services (e.g. Hutchings et al. 2004), so gender may influence the results for the welfare chauvinism model (sample is 52\% female). The relationship between gender and other 
immigration policies is unclear in that numerous studies find an insignificant relationship, some studies find significant relationship but in conflicting directions, and many studies do not include gender as a control variable.

\section{Results}

In the first section of the analysis, I primarily focus on the question, are authoritarians more likely to support welfare chauvinism than non-authoritarians? My results provide evidence supporting a hypothesis that a gap in preferences for welfare chauvinism exists between authoritarians and non-authoritarians. Authoritarians are more supportive of a waiting period with $85.2 \%$ holding this specific policy preference, while only $73.1 \%$ of non-authoritarians desire a waiting period (significant at $p$-value $<0.001$ ). ${ }^{9}$ The authoritarian gap is about $12.1 \%$. The correlation between authoritarianism and welfare chauvinism suggests a relationship with a value of 0.14 ( $p$-value $<0.001)$. In sum, this provides basic evidence that authoritarianism does shape preferences for welfare chauvinism.

In the next step of the analysis, I investigate if authoritarianism continues to predict support for welfare chauvinism after adding control variables because support for welfare chauvinism can be shaped by confounding factors that potentially influence the effect of authoritarianism. Authoritarianism, as a predisposition or worldview, holds an early and important position in the formation of political attitudes (Feldman 2003; Hetherington and Weiler 2009; Stenner 2005). As a result, authoritarianism may have an indirect effect on welfare chauvinism through other attitudes. Table 1 presents a series of models starting with authoritarianism and basic demographics (Model 1A). From this baseline model, I add "downstream" variables that may mediate the influence of authoritarianism. In Model 1B, I include political ideology and partisanship to the baseline. The third column, Model 1C, displays the model with addition of the prejudice measure. For my analysis and discussion of these results, I primarily focus on the influence of authoritarianism and prejudice on support for immigrant welfare chauvinism.

Starting with the first three models, authoritarianism is positively and significantly related at the 0.001 level to welfare chauvinism. This pattern of coefficients for authoritarianism is consistent with my expectations, that authoritarians are more likely to support a waiting period before immigrants can access

9 For the sake of simplification of the bivariate findings, I code authoritarians as individuals who score 0.75 or greater on the authoritarianism measure. Non-authoritarians are defined as individuals who score 0.25 or less. Hetherington and Weiler (2009) use the same coding for some of their findings. 
Table 1: The relationship between authoritarianism and welfare chauvinism.

\begin{tabular}{lrrr}
\hline & Model 1A & Model 1B & Model 1C \\
\hline Authoritarianism & $1.01^{\star \star \star}(0.24)$ & $1.04^{\star \star \star}(0.26)$ & $0.86^{\star \star}(0.28)$ \\
Prejudice & & & $0.32^{\star \star \star}(0.09)$ \\
Political ideology & & $-0.33(0.39)$ & $-0.05(0.07)$ \\
Party ID & & $0.42(0.27)$ & $0.07(0.05)$ \\
Income & $0.73^{\star}(0.31)$ & $0.59(0.34)$ & $0.09^{\star}(0.05)$ \\
Education & $-0.52^{\star}(0.24)$ & $-0.54(0.28)$ & $-0.10(0.10)$ \\
Age & $0.26(0.21)$ & $0.30(0.24)$ & $0.07(0.08)$ \\
Female & $0.02(0.14)$ & $0.08(0.15)$ & $0.06(0.42)$ \\
Log likelihood & -661.39 & -532.22 & -485.84 \\
Chi ${ }^{2}$ & 36.96 & 32.21 & 41.41 \\
Prob $>$ Chi ${ }^{2}$ & 0.001 & 0.001 & 0.001 \\
Pseudo $R^{2}$ & 0.03 & 0.03 & 0.043 \\
$\mathrm{~N}$ & 1350 & 1062 & 974 \\
\hline
\end{tabular}

Note: Entries are logit coefficients with robust standard errors in parentheses. ${ }^{\star} p<0.05$; ${ }^{\star \star} p<0.01$;

${ }^{\star \star \star} p<0.001$. Higher values on the above variables indicate greater support for a 1 -year waiting period before immigrants can access welfare programs (welfare chauvinism). Authoritarianism ranges from low authoritarianism (0) to high authoritarianism (1). Prejudice ranges from negative views ( -1 ) to positive views (1) of Latinos relative to Whites.

Source: 1992 ANES.

welfare programs. The substantive impact of authoritarianism on welfare chauvinism can be estimated using CLARIFY to simulate predicted probabilities (King, Tomz, and Wittenberg 2000; Tomz, Wittenberg, and King 2003). For each model, I estimate the first differences for authoritarianism while holding all other variables constant. ${ }^{10}$ The predicted probabilities for Models $1 \mathrm{~A}$ and $1 \mathrm{~B}$ are roughly the same. For the baseline model, Model 1A, authoritarians are 17.3\% more likely to support an immigrant waiting period. Controlling for ideology and partisanship, in Model $1 \mathrm{~B}$, results in basically the same predicted probability, $17.2 \%$, with the political variables held at mean values. In sum, the addition of political identifications does not alter the relationship between authoritarianism and welfare chauvinism. Authoritarianism is not operating through these political variables, at least not in 1992.

Consistent with previous research, I find that authoritarians are more likely to hold negative stereotypes of minorities (e.g. Hetherington and Weiler 2009; Stenner 2005). In this case, authoritarians are more likely to hold prejudicial views of Latinos $(r=-0.19, p<0.001)$ providing support that authoritarians are more

10 The probabilities are estimated by holding control variables at their mean for ordinal and interval data or mode for nominal data while shifting authoritarianism from the minimum to maximum values. 
likely to be prejudiced towards Latinos than non-authoritarians. Based on these basic results, authoritarians may express their dislike for an out-group through prejudice. To further explore this relationship, I include the Latino prejudice measure, which is negatively and significantly related to welfare chauvinism $(p<0.001)$, in Model 1C. Individuals who hold a negative perception of Latinos' work-ethic, relative to stereotypes of whites, are more likely to prefer exclusive welfare policies for immigrants. The authoritarianism coefficient remains significant at the 0.01 level. The substantive effect of authoritarianism on welfare chauvinism remains the same with a predicted probability of $17.4 \%$ for a first difference change in authoritarianism while holding all other variables constant and prejudice at its mean value. The predicted probability for authoritarianism does decrease to $9.4 \%$ among the most prejudiced individuals in the sample. The authoritarian gap is the largest between authoritarians and non-authoritarians who more positive stereotypes of Latinos with authoritarians being $24.2 \%$ more likely to support a waiting period before immigrants can access welfare programs.

These results indicate that the influence of authoritarianism is greatest among those with the least prejudice and that prejudicial authoritarians and nonauthoritarians hold more similar policy preferences.

\section{Discussion and Conclusion}

Several findings from my study have implications. First, the scholarly literature has long studied the importance of political and social attitudes, such as ideology, prejudice, economics, and core values, as predictors of individual support for immigration and welfare preferences (e.g. Gilens 1999; Hainmueller and Hiscox 2007; Peffley, Hurwitz, and Sniderman 1997). Additional studies link authoritarianism to immigration and welfare preferences (e.g. Hetherington and Weiler 2009; Rickert 1998). My results support the extension of many of these studies from welfare preferences in general to preferences for a waiting period before immigrants can receive benefits. In sum, these preferences go beyond political considerations, economic considerations, and prejudice but these attitudes are shaped by considerations regarding social conformity.

Second, the scholarly literature has long studied the importance of prejudice in the formation of political attitudes finding that prejudice can be extremely powerful in shaping policy preferences towards redistributive policies (e.g. Fording, Soss, and Schram 2011; Fox 2004; Gilens 1999; Johnson 2001; Peffley, Hurwitz, and Sniderman 1997) and immigrants (Brader, Valentino and Suhay 2008; Burns and Gimpel 2000; Chavez 2008; Lu and Nicholson-Crotty 2010). In a similar area of research, scholars find that authoritarianism is more likely to hold prejudicial stereotypes (Adorno 
et al. 1950; Feldman 2003; Hetherington and Weiler 2009; Stenner 2005). My findings indicate that prejudice has the largest impact on the authoritarian gap among the control variables. ${ }^{11}$ The largest authoritarian gap exists among individuals with the least prejudicial attitudes of Latinos. Non-authoritarians that view Latinos negatively are only slightly less likely than authoritarians to support a waiting period requirement for access to welfare benefits. In sum, authoritarianism has its largest effect among the least prejudiced individuals.

Third, a significant percentage, $73.2 \%$, of non-Latino whites with a nonauthoritarian worldview prefers creating a waiting period before immigrants can access welfare programs. In the early 1990s, political elites and media frames connected immigration as a threat to domestic spending programs, including welfare (Calavita 1996). Given the disproportionate number of media stories that picture Latinos as the face of contemporary immigration and portray immigrants as failing to adopt American social norms (Chavez 2008; Haynes, Merolla, and Ramakrishnan 2016) a preference for restricting access to welfare can gain support among non-authoritarians. While my findings are limited in scope due to data restricting the analysis to a single time point, the research on issue salience suggests that non-authoritarians may adopt restrictive immigration preferences during periods when immigration is portrayed by the media and political elites as a normative threat. During these salient periods of time, authoritarians and threatened non-authoritarians may form a political base that can potentially undermine liberal immigration policies through an opinion-policy linkage.

Acknowledgments: I would like to thank Richard Arnold, Emily Beaulieu, Adam Butz, Richard Fording, Walter Huber, Thomas Janoski, Mark Peffley, Ramesh Sharma, Mark Stambush, Lee Walker, Richard Waterman, Justin Wedeking, and the reviewers at Statistics, Politics, and Policy for their helpful feedback on earlier versions of this paper. Any errors are the contribution and responsibility of myself.

\section{References}

Abrajano, M., and Z. L. Hajnal. 2015. White Backlash: Immigration, Race, and American Politics. Princeton: Princeton University Press.

Adorno, T., E. Frenkel-Brunswick, D. Levinson, and N. Sanford. 1950. The Authoritarian Personality. New York: Harper \& Row.

Altemeyer, B. 1981. Right-Wing Authoritarianism. Winnipeg: University of Manitoba Press.

11 It is important to note that the result for partisanship has probably changed in more recent years as authoritarians have become more aligned with the Republican Party (Hetherington and Weiler 2009). 
Altemeyer, B. 1996. The Authoritarian Specter. Cambridge: Harvard University Press.

Altemeyer, B. 2003. "What Happens When Authoritarians Inherit the Earth? A Simulation." Analyses of Social Issues and Public Policy 3 (1): 161-9.

Anderson, B. 1983. Imagined Communities. London: Verso.

Banting, K.G. 2000. "Looking in Three Directions: Migration and the European Welfare State in Comparative Perspective." In Immigration and Welfare: Challenging the Borders of the Welfare State, edited by M. Bommes and A. Geddes, 13-33. London: Routledge.

Brader, T., N. A. Valentino, and E. Suhay. 2008. "What Triggers Public Opposition to Immigration? Anxiety, Group Cues, and Immigration Threat." American Journal of Political Science 52 (4): 959-78.

Burns, P., and J. G. Gimpel. 2000. "Economic Insecurity, Prejudicial Stereotypes, Public Opinion on Immigration Policy." Political Science Quarterly 115 (2): 201-29.

Butz, A., and J. E. Kehrberg. 2016. "Estimating Anti-Immigrant Sentiment for the American States Using Multi-Level Modeling and Poststratification, 2004-2008." Research \& Politics 3 (2): $1-7$.

Butz, A., and J. E. Kehrberg. 2019. "Anti-Immigrant Sentiment and the Adoption of State Immigration Policy.” Policy Studies Journal 47 (3): 605-23.

Calavita, K. 1996. "The New Politics of Immigration: "Balanced-Budget Conservatism" and the Symbolism of Proposition 187." Social Problems 43 (3): 284-305.

Carsey, T. M., and G. C. Layman. 2006. "Changing Sides or Changing Minds? Party Identification and Policy Preferences in the American Electorate." American Journal of Political Science 50 (2): 464-77.

Chavez, L. R. 2008. The Latino Threat: Constructing Immigrants, Citizens, and the Nation. Stanford: Stanford University Press.

Chong, D., and J. Druckman. 2007. "A Theory of Framing and Opinion Formation in Competitive Elite Environments." Journal of Communication 57 (1): 99-118.

Citrin, J., D. P. Green, C. Muste, and C. Wong. 1997. "Public Opinion Toward Immigration Reform: The Role of Economic Motivations." Journal of Politics 59 (3): 858-81.

Cizmar, A. M., G. C. Layman, J. McTague, S. Pearson-Merkowitz, and M. Spivey. 2014. “Authoritarianism and Political Behavior from 1952 to 2008." Political Research Quarterly 67 (1): 73-83.

Dustman, C., and I. P. Preston. 2007. "Racial and Economic Factors in Attitudes to Immigration." The B.E. Journal of Economic Analysis \& Policy 27 (1): 1-39.

Facchini, G., and A. Mayda. 2009. "Does the Welfare State Affect Individual Attitudes Toward Immigrants? Evidence across Countries." Review of Economics and Statistics 91 (2): 295-314.

Faist, T. 1994. "Immigration, Integration, and the Ethnicization of Politics." European Journal of Political Research 25 (4): 439-59.

Feldman, S. 2003. "Enforcing Social Conformity: A Theory of Authoritarianism." Political Psychology 24 (1): 41-74.

Feldman, S., and K. Stenner. 1997. “Perceived Threat and Authoritarianism.” Political Psychology 18 (4): 741-70.

Fording, R. C., J. Soss, and S. F. Schram. 2011. "Race and the Local Politics of Punishment in the New World of Welfare." American Journal of Sociology 116 (5): 1610-57.

Fox, C. 2004. "The Changing Color of Welfare? How Whites' Attitudes Toward Latinos Influence Support for Welfare." American Journal of Sociology 110 (3): 580-625.

Garand, J. C., P. Xu, and B. C. Davis. 2017. "Immigration Attitudes and Support for the Welfare State in the American Mass Public.” American Journal of Political Science 61 (1): 146-62. 
Gerber, A. S., G. A. Huber, D. R. Biggers, and D. J. Hendry. 2017. "Self-Interest, Beliefs, and Policy Opinions: Understanding How Economic Beliefs Affect Immigration Policy Preferences." Political Research Quarterly 70 (1): 155-71.

Gilens, M. 1999. Why Americans Hate Welfare: Race, Media, and the Politics of Antipoverty Policy. Chicago: Chicago University Press.

Hainmueller, J., and M. J. Hiscox. 2007. "Educated Preferences: Explaining Attitudes toward Immigration in Europe." International Organization 60 (2): 469-98.

Hainmueller, J., and D. J. Hopkins. 2014. "Public Attitudes toward Immigration." Annual Review of Political Science 17: 225-49.

Hanson, G., K. Scheve, and M. Slaughter. 2007. "Public Finance and Individual Preferences over Globalization Strategies." Economics and Politics 19 (1): 1-33.

Haynes, C., J. Merolla, and S. K. Ramakrishnan. 2016. Framing Immigrants: News Coverage, Public Opinion, and Policy. New York: Russell Sage Foundation.

Hero, R., and R. Preuhs. 2007. "Immigration and the Evolving American Welfare State: Examining Policies in the U.S. States." American Journal of Political Science 51 (3): 498-517.

Hetherington, M. J., and E. Suhay. 2011. “Authoritarianism, Trust, and Americans' Support for the War on Terror." American Journal of Political Science 55 (3): 546-60.

Hetherington, M. J., and J. D. Weiler. 2009. Authoritarianism \& Polarization in American Politics. Cambridge: Cambridge University Press.

Hetherington, M. J., and J. D. Weiler. 2015. "Authoritarianism and Polarization in American Politics, Still?" In American Gridlock: The Sources, Character, and Impact of Political Polarization, edited by J.A. Thurber and A. Yoshinkaka, 86-112. Cambridge: Cambridge University Press.

Hopkins, D. J. 2009. "Partisan Reinforcement and the Poor: The Impact of Context on Explanations for Poverty." Social Science Quarterly 90 (3): 744-64.

Huntington, S. P. 2004. Who are We: The Challenges to America's National Identity. New York: Simon \& Schuster.

Hurwitz, J., and M. Peffley. 1992. "Traditional Versus Social Values as Antecedents of Racial Stereotyping and Policy Conservatism.” Political Behavior 14 (4): 395-421.

Hurwitz, J., and M. Peffley. 1997. "Public Perceptions of Race and Crime: The Role of Racial Stereotypes." American Journal of Political Science 41 (2): 375-401.

Hutchings, V., N. Valentino, T. Philpot, and I. White. 2004. "The Compassion Strategy: Race and the Gender Gap in American Politics.” Public Opinion Quarterly 68 (4): 512-41.

Johnson, M. 2001. "The Impact of Social Diversity and Racial Attitudes on Social Welfare Policy." State Politics and Policy Quarterly 1 (1): 27-49.

Katz, D. 1960. "The Functional Approach to the Study of Attitudes." Public Opinion Quarterly 24 (2): 163-204.

Kehrberg, J. E. 2017. "The Mediating Effect of Authoritarianism on Immigrant Access to TANF: A State-Level Analysis.” Political Science Quarterly 132 (2): 291-311.

Kinder, D. R., and C. D. Kam. 2009. Us Against Them: Ethnocentric Foundations of American Opinion. Chicago: The University of Chicago Press.

Kinder, D. R., and T. Mendelberg. 1995. "Cracks in American Apartheid: The Political impact of Prejudice among Desegregated Whites." Journal of Politics 57 (2): 402-24.

King, G., M. Tomz, and J. Wittenberg. 2000. "Making the Most of Statistical Analyses: Improving Interpretation and Presentation." American Journal of Political Science 44 (2): 347-61.

Lahav, G. 2004. Immigration and Politics in the New Europe. Cambridge: Cambridge University Press. Lahav, G., and M. Courtmanche. 2012. "The Ideological Effects of Framing Threat on Immigration and Civil Liberties.” Political Behavior 34 (3): 477-505. 
Lahav, G. 2013. "Threat and Immigration Attitudes in Liberal Democracies: The Role of Framing in Structuring Public Opinion.” In Immigration and Public Opinion in Liberal Democracies, edited by G. P. Freeman, R. Hansen and D. L. Leal, 232-53. New York: Routledge.

Lieberman, R. C. 2003. "Race and the Limits of Solidarity: American Welfare State Development in Comparative Perspective." In Race and the Politics of Welfare Reform, edited by S. F. Schram, J. Soss, and R. C. Fording, 23-46. Ann Arbor: The University of Michigan Press.

Lippmann, W. 1922. Public Opinion. New York: Free Press.

Lu, L., and S. Nicholson-Crotty. 2010. "Reassessing the Impact of Hispanic Stereotypes on White Americans' Immigration Preferences.” Social Science Quarterly 91 (5): 1312-28.

Manevska, K., and P. Achterberg. 2013. "Immigration and Perceived Ethnic Threat: Cultural Capital and Economic Explanations." European Sociological Review 29 (3): 437-49.

Mayda, A. M. 2006. "Who is Against Immigration? A Cross-Country Investigation of Individual Attitudes Toward Immigrants." The Review of Economics and Statistics 88 (3): 510-30.

McDaniel, E. L., I. Nooruddin, and A. F. Shortle. 2011. "Divine Boundaries: How Religion Shapes Citizens’ Attitudes Towards Immigrants.” American Politics Research 39 (1): 205-33.

Miller, D. 1995. On Nationality. Oxford: Oxford University Press.

Monogan, J. E., , III. 2013. “The Politics of Immigrant Policy in the 50 U.S. States, 2005-2011." Journal of Public Policy 33 (1): 35-64.

Nelson, T. E., and D. R. Kinder. 1996. "Issue Frames and Group-Centrism in American Public Opinion.” Journal of Politics 58 (4): 1055-78.

Nelson, T. E., R. A. Clawson, and Z. M. Oxley. 1997. "Media Framing of a Civil Liberties Conflict and Its Effect on Tolerance." American Political Science Review 91 (3): 567-83.

Paxton, P., and A. Mughan. 2006. "What's to Fear from Immigrants? Creating an Assimilationist Threat Scale.” Political Psychology 27 (4): 549-68.

Peffley, M., and J. Hurwitz. 1997. "Whites' Stereotypes of Blacks: Sources and Political Consequences." In Perception \& Prejudice: Race and Politics in the United States, edited by J. Hurwitz and M. Peffley, 58-99. New Haven: Yale University Press.

Peffley, M., and J. Hurwitz. 2010. Justice in America: The Separate Realities of Blacks and Whites. Cambridge: Cambridge University Press.

Peffley, M., J. Hurwitz, and P. Sniderman. 1997. "Racial Stereotypes and Whites' Political Views of Blacks in the Context of Welfare and Crime." American Journal of Political Science 41 (1): 30-60.

Piston, S. 2010. “How Explicit Racial Prejudice Hurt Obama in the 2008 Election.” Political Behavior 32 (4): 431-51.

Quillian, L. 1995. "Prejudice as a Response to Perceived Group Threat: Population Composition and Anti-Immigrant and Racial Prejudice in Europe." American Sociological Review 60 (4): 586-612.

Rickert, E. J. 1998. “Authoritarianism and Economic Threat: Implications for Political Behavior.” Political Psychology 19 (4): 707-20.

Scheepers, P., M. Gijsberts, and M. Coenders. 2002. "Ethnic Exclusionism in European Countries. Public Opposition to Civil Rights for Legal Migrants as a Response to Perceived Ethnic Threat." European Sociological Review 18 (1): 17-34.

Scheve, K., and M. Slaughter. 2001. "Labor Market Competition and Individual Preferences over Immigration Policy.” Review of Economics and Statistics 83 (1): 133-45.

Schildkraut, D. 2011. Americanism in the Twenty-First Century: Public Opinion in the Age of Immigration. Cambridge: Cambridge University Press.

Sniderman, P. M., and T. Piazza. 1993. The Scar of Race. Cambridge: Harvard University Press. 
Sniderman, P. M., and E. G. Carmines. 1997. Reaching Beyond Race. Cambridge: Harvard University Press.

Sniderman, P. M., L. Hagendoorn, and M. Prior. 2004. "Predisposing Factors and Situational Triggers: Exclusionary Reactions to Immigrant Minorities." American Political Science Review 98 (1): 35-49.

Soss, J., R. C. Fording, and S. F. Schram. 2011. Disciplining the Poor: Neoliberal Paternalism and the Persistent Power of Race. Chicago: University of Chicago Press.

Stenner, K. 2005. The Authoritarian Dynamic. Cambridge: Cambridge University Press.

Theiss-Morse, E. 2009. Who counts as an American? The Boundaries of National Identity. Cambridge: Cambridge University Press.

Tomz, M., J. Wittenberg, and G. King. 2003. CLARIFY: Software for Interpreting and Presenting Statistical Results. Stanford University, University of Wisconsin, and Harvard University. January 5. Available at http://gking.harvard.edu/.Version 2.1.

Voss, D. S., J. E. Kehrberg, and A. M. Butz. 2013. "The Structure of Self-Interest(s): Applying Comparative Theory to US Immigration Attitudes." In Immigration and Public Opinion in Liberal Democracies, edited by G. P. Freeman, R. Hansen and D. L. Leal, 93-128. New York: Routledge.

Walker, L. D. 2009. "Delegative Democratic Attitudes and Institutional Support in Central America." Comparative Politics 42 (1): 83-101.

Wilcox, C., L. Sigelman, and E. Cook. 1989. "Some Like it Hot: Individual Differences in Responses to Group Feeling Thermometers.” Public Opinion Quarterly 53 (2): 246-57. 